\title{
A Review on Production and Marketing of Mango Fruit
}

\author{
Kayier Guien Chay ${ }^{1 *}$, Amsale Workeneh ${ }^{2}$ and Beshadu Shifera ${ }^{3}$ \\ ${ }^{1}$ Department of Agricultural Economics, Gambella University College of Agriculture and Natural resource Management, Gambella, Ethiopia \\ ${ }^{2}$ Department of Agricultural Economics, Gambella University College of Agriculture and Natural resource Management, Gambella, Ethiopia \\ ${ }^{3}$ Department of Agricultural Economics, Assosa University College of Agriculture and Natural resource Management, Ethiopia
}

*Corresponding author: Kayier Guien Chay, Department of Agricultural Economics, Gambella University College of Agriculture and Natural resource Management, Gambella, Ethiopia.
Received Date: April 23, 2019

Published Date: May 13, 2019

\begin{abstract}
This review paper focuses on production and marketing of edible fruit like mango. Fruit crops play an important role in the national food security of people around the world. They are generally delicious and highly nutritious, mainly of vitamins and minerals that can balance cereal-based diets. Fruits supply raw materials for local industries and could be sources of foreign currency. Moreover, the development of fruit industry will create employment opportunities, particularly for farming communities. Mango (Mangifera Indica) is a fleshy stone fruit belonging to the panes Mangifera, consisting of numerous tropical fruiting trees in the flowering plant family Anacardiaceous. This review paper was carried out on production and marketing of mango fruit and the main objective is to review the production and marketing base of mango fruit for farm communities which encompass marketing channels, production practice, paste control mechanisms, market structure, marketing conduct and performance. Information flow on marketing production and marketing constrains was also looked from different sources. Finally, it was argued that market conduct and performance had been low due to traditional production practice and marketing constrains. Therefore, awareness should be created on modern production system of mango and convenience environment should be set on marketing system of mango that need to reduce cost.
\end{abstract}

Keywords: Production; Marketing; Conduct; Performance; Market channel

\section{Introduction}

Fruit crops play an important role in the national food security of people around the world. They are generally delicious and highly nutritious, mainly of vitamins and minerals that can balance cerealbased diets. Fruits supply raw materials for local industries and could be sources of foreign currency. Moreover, the development of fruit industry will create employment opportunities, particularly for farming communities. In general, Ethiopia has great potential and encouraging policy to expand fruit production for fresh market and processing both for domestic and export markets. Besides, fruit crops are friendly to nature, sustain the environment, provide shade, and can easily be incorporated in any agro-forestry programs [1].

The fruit sector in Ethiopia has high value products as compared to other crops and promises high returns on relatively small investments. However, the investments on production and processing are small. The study by James et al. (2008) indicated that the study of fruit value chain in Ethiopia is quite rudimentary with mainly subsistence level cultivation, harvesting and post-handling techniques which limit the quality of the fruit [2].
Mango (Mangifera indica) is a fleshy stone fruit belonging to the panes Mangifera, consisting of numerous tropical fruiting trees in the flowering plant family Anacardiaceae. The mango is native to the south Asia from where it was distributed worldwide to become one of the most cultivated fruit in the tropics. Mango (Mangifera indica) is produce in most frost free tropical and sub-tropical climates, more than 85 countries in the world cultivate mango. The total production area of mango in the world is around 3.69 million hectares. The total amount of mango production in the world is around 35 million tons by the year 2009 [3].

In Ethiopia mango produced mainly in west and east of Oromia, SNNPR, Benshangul and Amhara. Mango production in Ethiopia is in fluctuated conditions, because of occurrence of diseases, lack of proper management and also weather conditions [3].

Some studies like [1] argue that mango, because of its attractive appearance and the very pleasant taste of selected cultivars, is claimed to be the most important fruit of the tropics and has been 
touted as 'king of all fruits'. The fruit contains almost all the known vitamins and many essential minerals. The protein content is generally a little higher than that of other fruits except the avocado. Mangos are also a fairly good source of thiamine and niacin and contain some calcium and iron.

Tewodros Bezu et al [1] argue that there is remarkable variability among the existing mango trees and fruits since almost all growers propagate it sexually even though other variables like ecological, edaphic factors and crop husbandry practices could contribute to the variation. This is in line with the study of Griesbach, (2003) that articulate the potentials of mango production but demands serious attention to the existing trees with regard to promotion of potential germplasm by grafting propagation method and use of appropriate husbandry practices.

Moreover, maintaining as many mango varieties as possible is necessary as a basis for breeding activities, which allows the development of better adapted and pest/disease-tolerant varieties with a high value for domestic and export markets. Focus should be given in improving the production, productivity and marketing of the crop in order to utilize the available and adaptable mango ecotypes which are on the verge of disappearance [1].

\section{General objective}

General objective is to take a looks on production and marketing of mango fruit.

\section{Specific objectives}

- The author is intended to review market structure, conduct, and performance of mango fruit.

- The author is intended to review production and marketing constrains of mango fruit.

\section{Production of Mango in Ethiopia}

According to CSA (2012/2013), about 61,972.6 hectares of land is under fruit crops in Ethiopia; mangoes contributed $14.2 \%$ of the area. Moreover, out of 479,336 tons of fruits produced in the country, mangoes accounted $14.5 \%$ fruit production. In Ethiopia, mango is produced mainly in Harari region, west and east Oromia, Southern Nations, Nationalities, and People's Region (SNNPR) and Amhara which is in line with the study of [3].

Wiersinga and Jager (2007) stated that, Eastern Ethiopia (Dire Dawa and Harar areas) is well-known for production and supply of both fruits and vegetables and about $35 \%$ of the total acreage allotted for fruit production is covered by Mango (Unpublished Haramaya University Horticulture Department Survey, 1996).

Ishot (2009) stated the area covered by fruit crops in Harari People National Regional State by the year 2004/2005 was about 163 ha owned by a total of 5,171 peasant holders altogether produced 30 ton. Out of this, the area occupied by mango was 115ha. In Harari region, mango is grown dominantly in the central and lower parts of the Bisidimo and Erer River basins including in the vicinities of the Harar city [1].
A comparative study made between income from fruit growing and cereals (sorghum and maize) in Harar by TAM Agribusiness (2004) revealed that the annual income from fruit growing such as mango and custard apple was ETB 60,000/ha/yr compared to 2,000 for maize and only 1,000 for sorghum. Even if the farmer's livelihood is highly supplemented by the income from their mango trees, there is a declining trend in yield and quality of the fruits from the trees. Some of the factors contributing to this include foliar diseases, old age, poor management and variability of the trees. Except the farmers' traditional naming for identification, the trees are mixed and difficult for identification [1].

Attempt was made by Griesbach, 2003 cited by [1] to assess age of the mango trees in relation to their productivity, but almost all of the farmers responded that they didn't know the exact age of their trees rather they estimated them to be more than 80 years old. This appears to hold true as mango tree is long-lived with some specimens known to be over 150 years old and still producing fruit.

Farmer awareness about spacing of orchards, pruning, fertilizer application, access of new varieties and pest and disease control is very low. In order to increase the production of mango, many actions have to be taken. Training about agronomic practices such as proper spacing, time of pruning, methods and time of fertilizer application, identification of pest and disease and control mechanism, methods and time of harvesting, kind of packing materials used, are vital to increase the productivity of mango. Distribution of pest and disease resistance and early maturing varieties is another method to increase production potential (Seid Hussena, and Zeru Yimer(nd)).

The mango industry in Ethiopia is in its infant stage. However, mango is grown in many parts, especially in the Rift Valley, western and south western parts of the country. The national research system has developed a number of varieties but is not widely spread. Experiences from other countries in growing this crop will therefore contribute to the success and widespread of this fruit [1].

CSA [10] showed as mango is one of the second potential fruit crop produced in Ethiopia next to banana which is the first fruit crop produced in large quantity.

\section{Product and Information Flow}

It is common in Ethiopia that majority of mango producers sell their products to middlemen and nearby local village market. The producers often have low amount of information as the farmers and traders often do not have any direct communication about price information with each other but only through middleman. But some of the farmers have direct communication about the price and amount of product [4].

\section{Management Practices}

Nearly the entire mango ecotypes reviewed were planted without any pattern and recommended spacing and also pruning of the trees was not practiced. Overcrowding results in the production of fewer fruits which are apt to be poorly colored and infected with diseases. Tall trees also present a harvesting problem and create 
difficulties during spraying and pruning. In general, well managed orchard trees require regular annual pruning to maintain an open canopy of manageable size. This allows air and sunlight to penetrate, which reduces pests and diseases and enhances fruit color [1].

Nearly $70 \%$ of the growers did not supplement their trees with any form of fertilizer but some (26\%) use organic fertilizers such as compost and manure. However, the rates of fertilizer required for mango trees have not yet been standardized for the study area. Mango trees are usually left unfertilized once established. This is in accord with the study by [3] who reported that $90 \%$ of growers in northern Ethiopia did not apply neither inorganic nor organic fertilizer on their farmland [1].

Regarding pests and their management, the respondents pointed out that the major insect pests were fruit fly, trips and termites while diseases included powdery mildew and anthracnose. Both diseases are known to be most common during wet weather in Ethiopia. For the management of the aforementioned pests, cultural practices like smoking are used especially during flowering and sanitation measures via removing diseased branches and weeding due to several factors such as unavailability of pesticide, technical problems in spraying tall trees and economic issues [1].

Moreover, postharvest handling problems were observed. About $91 \%$ of the growers transport their produce in synthetic fiber sacks while very few (8\%) use wooden box and transport to the market by animals like donkey, car and by the farmers themselves to the nearby village market. Plastic crates, which are stackable, stable, easy to clean and reuse has been shown to reduce damage of perishable crops from an average of $30 \%$ to less than $10 \%$ [1]. This is in accord with the study conducted by [1].

\section{Mango Production Constraints}

The major production constraints were water shortage or erratic rainfall followed by pest problems. Lack of knowledge and recommended production practices (nutrition, pruning, pest management etc.) and post-harvest losses were also noted as major problems of the growers. It is in agreement with CSA [5] report that stated mango production in Ethiopia fluctuates because of occurrence of diseases and lack of proper management [4] and [7] report indicated in addition to the lack of improved varieties, the development of fruit production was severely hampered by lack of knowledge and skills, in particular on the production of grafted seedlings pilot learning districts in north and southwest of Ethiopia.

Furthermore, the major issue restraining the development of the mango industry in Ethiopia is the lack of organization like a farmer organization or cooperative amongst mango growers narrated by (James, et.al, 2008) cited by [1]. Due to the highly seasonal nature of the mango crop, and also the tendency to prioritize food security with grain crops, mango growing is not the main livelihood activity for most farmers and is generally considered a complementary activity to other farming practices (James, et.al, 2008) cited by [1].

Likewise, absence of good marketing system that could benefit or attract the growers is the additional bottleneck raised. As a result, the growers reflected their tendency towards cultivation of other cash crops like khat (Catha edulis) by uprooting the exiting trees. The tendency to shift to other cash generating crops is also most common in other parts of the country [3].

\section{Mango Marketing, Market Outlets and Transportation Means}

It is common in Ethiopia that majority of mango producers sell their products at nearby local market. Most of the time mango producers sell their produce to consumers and sometimes to retailers because of the market fluctuation and lack of marketing infrastructures. The other reason is maturity stage and harvesting time of mango fruit is similar. This condition increases the supply at that time and the demand is less compare to that of the supply. In this situation the price of the fruit become less and less and as result of this farmer are obliged to sale their produce at local market [3].

In addition to this, farm gate sale of mango is also common in Ethiopia. The main sales channels of mango in Ethiopia include direct sale to consumer, hotels, large retailers and supermarkets, wholesalers and small retailers and kiosks [6]. During marketing of mango, smallholder farmers use pack animal, human back, cart and car as means of transportation to deliver their produce to final sale. Mango producing farmers in Ethiopia use basket, can, plastic box and wooden box to pack mango in order to keep safety and postharvest loss of mango during transportation [3].

\section{Mango Value Chain Actors and Their Functions}

Study conducted by [7] in Jimma zone of Ethiopia indicated that market participants along mango value chain in the study areas are producer, local collectors, wholesalers, retailers, processors and final consumers of the product. Producers are the primary or first link actors who cultivate and supply mango to the market. Local collectors are farmers or part time traders in assembly markets who collect mango from farmers in village markets for the purpose of reselling it to wholesalers, retailers and consumers. They use their financial resources and their local knowledge to bulk mango from the surrounding area. Wholesalers are known for purchase of bulky products with better financial and information capacity. They are major actors in the channel, and they purchase mango either directly from farmer or local collectors. They procure and consign large amount of mango to the regional market and to terminal markets. Retailers are the ultimate actors in the market chain that purchase and deliver mango to consumers. Processors are those value actors like cafes, restaurants and juice houses which change mango fruit into processed goods like juice. Consumers are those households who bought and consume mango. They are individual households who bought the commodity for their own consumption only. James et.al, (2008) study of mango value chain in Ethiopia identified mango value chain actors as mango producers/growers, wholesalers (local mango collectors, regional mango collectors/ bulkers), retailers, processors such as hotels and consumers. According to [8] the major actors in the mango value chain are the producers, traders and consumers. The producers are mainly smallholder farmers who supply the product to the local traders, 
cooperatives, retailers and consumers. The traders sell to Ethiofruit, wholesalers, retailers or consumers.

The main actors along value chain of apple mango were input suppliers, producers, wholesalers, retailers and consumers. The function of input supplier is providing different types of production inputs to mango producers. That of producer is to produce mango and sell to the next actor. That of wholesaler is to collect mango from farmers in bulk and then sell to other actors - retailers or consumers. That of retailer is to purchase mango product from farmers directly or from wholesalers then distributes it to the end users [9].

The fruit sector in Ethiopia has high value products as compared to other crops and promises high returns on relatively small investments. However, the investments on production and processing are [10]. The study by James et al. (2008) indicated that the study of fruit value chain in Ethiopia is quite rudimentary with mainly subsistence level cultivation, harvesting and post-handling techniques which limit the quality of the fruit. [2].

Though there are indications of the expansion of agro-industries that are involved in value addition and expansion of markets for agricultural products, value addition by Ethiopian farmers for major agricultural commodities is limited to transportation. Marketing of fruit products in Ethiopia is currently facing tremendous challenges such as poor quality and safety practices in the production, marketing and processing, and absence of formal rules, grades and standards in the production and marketing of the products [9].

Ethiopian farmer faces serious problem in marketing of the farm produce. This is due to lack of know-how about marketing system, unavailability of market information, shortage of supply of quality seed, inappropriate post-harvest management and low bargaining power of farmers. Even if attempts are made by the government to improve the marketing skill and bargaining power of farmers through establishment of cooperatives and promotion of other group action approaches, the bargaining power is still in the hands of the traders [9].

\section{Mango Market Channel}

Eight marketing channels are exhibited according to the study carried out by [11], where all channels remained in the region. Accordingly, producer-wholesaler-retailer-consumer channel procure the largest volume of products ( 40 percent) followed by producer local collector-wholesaler retailer consumer channel which accounted for $20 \%$ of the total mango bought from the market. The volume that passed through producer-wholesalerretailer-consumer channel is the most important since it accounted the largest marketed volume (40\%). This is in accord with the study of [3].

\section{Producer-Retailer-Consumer Channel:}

It represented $10 \%$ of the total mango. The channel was identified to be the fourth important mango marketing channel in terms of volume.

\section{Producer-Processor-Consumer Channel:}

It accounted for $15 \%$ of total mango marketed. The channel was found to be the third important channel in terms of volume.

III. Producer-Local Collectors Processor-Consumer Channel:

It accounted for $3 \%$ of total mango marketed. The channel was found to be the least important in terms of volume.

IV. Producer-Wholesaler-Processor-Consumer Channel:

It accounted for $4 \%$ of total mango marketed. The channel was found to be the second least important in terms volume.

V. Producer-Local

Collectors-Wholesaler-RetailerConsumer Channel:

It represented $20 \%$ of total mango marketed. The channel was found to be the second most important marketing channel in terms of volume.

\section{Producer-Wholesaler-Retailer-Consumer Channel:}

It accounted for $40 \%$ of total mango marketed. The channel was found to be the first important in terms volume.

VII. Producer-Consumer Channel:

Represented $5 \%$ of the total mango marketed. The channel is the fifth important mango marketing channel in terms of volume.

\section{Estimating Cost and Margin of Mango Production and Marketing}

The major cost items involved in mango production of the include cost of hired labor, fertilizer, pesticide and fuel for irrigation said by Bereket Gebremedhin et al, 2015. The costs/qt of mango varies across households depending on the number of days taken up by for pre-harvest activities, number of hired labor, and sources of irrigation water. Since the production methods used by the households are mainly traditional, most of the pre-harvest and post-harvest activities were done using manual labor.

Table 1: Costs and margins of apple mango along the value chain.

\begin{tabular}{|c|c|c|c|c|}
\hline Items & Producer & Wholesalers & Retailers & \\
\hline $\begin{array}{l}\text { Production Cost } \\
\text { (birr/qt) }\end{array}$ & 187.5 & & & \\
\hline $\begin{array}{l}\text { Purchase Cost } \\
\text { (birr/qt) }\end{array}$ & & 1800 & 2250 & \\
\hline $\begin{array}{l}\text { Marketing Cost } \\
\text { (birr/qt) }\end{array}$ & 26.85 & 119.586 & 103 & \\
\hline Total Cost (birr/qt) & 214.35 & 1919.5 & 2353 & \\
\hline $\begin{array}{c}\text { Sales Price (birr/ } \\
\text { qt) }\end{array}$ & $\begin{array}{l}1800(18 \\
\text { birr/kg) }\end{array}$ & $\begin{array}{c}2250(22.5 / \\
\mathrm{kg})\end{array}$ & $\begin{array}{c}2850 \\
(28.5 / \mathrm{kg})\end{array}$ & \\
\hline $\begin{array}{l}\text { Margin/Value } \\
\text { Added }\end{array}$ & 1583.65 & 330.5 & 497 & 2411.15 \\
\hline $\begin{array}{l}\text { Percent Value } \\
\text { Added }\end{array}$ & 65.68 & 13.71 & 20.61 & 100 \\
\hline
\end{tabular}

Source: Computed from the field survey data [2].

In addition to the production cost, the farmers incur marketing costs. Marketing costs of mango include loading-unloading cost, 
transportation cost, packaging cost, storage cost, tax if any and other payments for marketing functions [9] (Table 1).

\section{Mango Value Chain Constraints and Opportunities}

\section{Production constraint}

Major constraints of the mango production in the area were identified. Accordingly, some of the major constraints include shortage of timely input supply, lack of management skill, expensive price of inputs, and incidence of diseases that damage their mango, lack of harvesting technology, theft and free grazing of animals were some of the problem faced by mango producers during the production time [9].

Shortage of input supply: Shortage of inputs like pesticides, motor pump and its fuel were the main problems raised by mango producers. Even if these inputs are supplied to the producer by agriculture and rural development office of the district their supply is limited in amount and not on time. In addition to timely inaccessibility of the inputs its price is very expensive, and it is beyond the purchasing power of the farmers; i.e. price of fertilizer, pesticides and motor pump are examples of the most expensive inputs [9].

\section{Lack of management skill}

This problem is related with farmer's lack of knowhow on management practices. Most mango producers do not know how to apply fertilizer, manure, compost and pesticide to their mango. Farmers also suffer from problems like identification of different type of diseases, example cause for removal of mango flower before giving product which was the headaches for almost all farmers and even for the agriculture experts [9].

Marketing constraint: Marketing problems forwarded by farmers and traders include lack of market information, high competition during peak production period; which lowers price of mango, grading problem, quality problem because of pre-mature harvest of mango, lack of market linkage among value chain actors, price variation, problem of road and transportation and etc. said by [2]. This is in accord with the study of [1].

Market information is not available on time for farmers. Farmers get market information particularly price information from informal sources of information like; their friends, neighbors and traders which is inaccurate; hence farmers do not have price said by [12]. The linkage among market actors was very week even farmers they do not know their permanent buyers and they do not get any support and advice from the individuals within the value chain. Framers harvest their product early before maturity to fulfill their cash demand (cash obligation); hence the quality and testy of the product decrease. Lack of organized marketing linkage was other marketing problem of the study area. There was no wellorganized market organization for mango product it results in lack of grading and standardizing of the product, poor quality control, and inadequate and inconsistent supply to the next actors in the chain.
The other marketing problems from the trader side were perishable nature of the product and existence of illegal traders. Illegal traders are traders who buy the product from wholesaler and sell it at road side and they are not licensed. They sell the product at prices less than retailers' price, and this highly affects the pricing system and profit of legal traders particularly the retailers [9].

\section{Opportunities along Mango Value Chain}

The opportunities refer to the external favorable conditions that are in favor of mango production. It includes favorable weather conditions for mango production, good strategic location for mango production, access to irrigation water and access to seed. Mango is one of the tropical fruits that can be produced in low land areas and hence its agro-ecology is suitable for mango production. Marketing opportunity of mango product includes high demand of the product and access to local market for mango producers [9].

\section{Market Structure}

Market structure in fruit marketing is analyzed based on the number of buyers and sizes of enterprises within the system, the degree of market transparency (market information), and the condition of entry to and exit from trade. In this review it was found that the market structure of mango is assessed using market concentration ratio, degree of market transparency, flow of market price information within markets, and condition of entry into and exit from trade. Consequently, study conducted in Arba Minch argue that educational level, trade experience, lack of working capital and policy barriers are used as a clue to examine the fruit market structure [1].

The study results in [1] shows that the market concentration for mango is $22.69 \%$. This indicates that mango markets were characterized by the prevalence of unconcentrated suppliers/ traders/sellers. Therefore, following the market structure criteria suggested by Kohls and Uhl (2002) cited by [12] mango market showed competitive nature with CR4 of $22.69 \%$.

Regarding market transparency, the assessment on the continuum indicated, only $20 \%$ and $43 \%$ of producers and traders respectively have reported as they have adequate, timely and reliable information said by [13]. The research result has implied that, the market is well characterized by lack of transparency in timeliness and reliability. The result has also ascertained that traders have more privilege of information access than producers. The traders' survey result has indicated that about $75 \%$ of the sample traders got price information through combination of telephone, personal observation and other traders. The rest (25\%) of the traders reported that they could guess market information from the acts of other traders (e.g. interest to buy large volume of mango at higher prices) [1].

\section{Market Conduct}

Market conduct refers to the patterns of behavior of firms. This implies analysis of human behavioral patterns that are not readily identifiable, obtainable, or quantifiable. There are no agreed upon 
procedures for analyzing the elements of market conduct. Rather some points are put to detect unfair price setting practices, and the conditions under which such practices prevail. Some of the studies like that of [1] argue that conduct of mango market is analyzed in terms of the traders' and price setting, purchasing and selling strategies.

\section{Producers' Market Conduct}

The research result conducted by [1] pointed out that, supply of mango occurs mainly from April to October. November to March is months when prices of mango reach highest, while May to June is months when mango prices are lowest. According to the assessment mango was highly supplied to market from months of May and June. The lack of modern post-harvest handling practice, and lack of facilitated storage facilities have compelled producers to sell the fruits at prevailing prices. Knowing this, wholesalers put pressure on producers to sell at low price. Starting from production up to marketing, every farmer produces and sells on individual basis. This affected their bargaining power during the sale of mango.

\section{Price setting and Terms of Payment}

The assessment indicated that $90.5 \%$ of the farmers have reported as they don't negotiate on price to sell their produce; indicating this large number of producers are price takers. But 92.3 $\%$ of the farmers stated the term of payment is conducted through cash in hand system. The selling strategy of the farmers was open to any buyer. Thus, all producers sell their produce to anybody as far as they offer better price [17]. This study is in line with the study of [2].

The result in [12] shows that $94.3 \%$ of the respondents indicated that fruit price was set by demand and supply interaction. This means that buyers and sellers negotiate in the process and finally agree to exchange the products with the agreed up on price.
But only in rare cases $(5.7 \%)$ the producers set at the price. The selling strategy of the respondent farmers is open to any buyer. This is in line with [7] who stated that the greater proportion of price for avocado and mango was set by demand and supply interaction and the selling strategy of the respondent farmers was open to any buyer (Table 2).

Table 2: Pricing system of apple mango.

\begin{tabular}{|c|c|c|}
\hline Factors Governing Price of Mango & Frequency & Percentage \\
\hline Season of the Year & 36 & 28.571 \\
\hline Quality of the Product & 46 & 36.508 \\
\hline Distance from Market & 8 & 6.349 \\
\hline $\begin{array}{c}\text { Season of the Year and Quality of the } \\
\text { Product }\end{array}$ & 36 & 28.571 \\
\hline $\begin{array}{c}\text { Price Determination } \\
\text { Producers }\end{array}$ & 34 & 26.984 \\
\hline The Market Itself & 88 & 69.841 \\
\hline Purchaser & 4 & 3.174 \\
\hline
\end{tabular}

Source: Own computational result from field survey [9].

\section{Traders' Market Conduct}

\section{Place to sell}

The survey result conducted by [1] indicated that, almost all transactions made on mango marketing took place with direct contact between sellers and buyers. Similarly, $38 \%$ of mango traders purchase the fruit directly from the farmers at farm gate, while 25,20 , and $17 \%$ of mango traders purchase the fruit at village markets and roadside market, respectively. This is in line with Dawit and Hailemariam (2004), who stated that, three different selling options for horticultural crops which include: right in the field, sell at nearby markets, and least proportion option to access distance markets.

\section{Marketing Performance}

Table 3: Market performance of Mango in terms of marketing margin with respect to the share of actors in each channel.

\begin{tabular}{|c|c|c|c|c|c|}
\hline Actors & Price in birr & Channel 1 & Channel 2 & Channel 3 & Channel 4 \\
\hline \multirow[t]{3}{*}{ Producer } & Selling Price & 180 & 160 & 170 & 170 \\
\hline & Farmers Share \% & 100 & 80 & 73.9 & 77.3 \\
\hline & TGMM \% & & 20 & 26.1 & 22.7 \\
\hline \multirow[t]{4}{*}{ Local Collector } & Selling Price & & & 195 & 220 \\
\hline & Margin & & & 25 & 50 \\
\hline & Marketing Margin \% & & & 10.9 & 22.7 \\
\hline & TCMMa \% & & & 41.8 & 100 \\
\hline \multirow[t]{4}{*}{ Retailer } & Selling Price & & 200 & 230 & \\
\hline & Margin & & 40 & 35 & \\
\hline & Marketing Margin \% & & 20 & 15.2 & \\
\hline & TCMMr \% & & 100 & 58.2 & \\
\hline Final Consumer Price & & 180 & 200 & 230 & 220 \\
\hline TCMM & & & 40 & 60 & 50 \\
\hline
\end{tabular}

Source: Survey result Nega Mateows, et al. [12].

From [12], the farmer's share of the total consumer price for mango fruit was $100 \%$ in channel $\mathrm{I}, 80 \%, 73.9 \%$ and $77.3 \%$ in channel II, III and IV respectively. This implies that $20 \%$ of the total consumer price in channel II, $26.1 \%$ of the total consumer 
price in channel III and $22.7 \%$ of the total consumer price in channel IV results from marketing activities by traders. Without considering channel I (producers sell directly to consumer) the total gross marketing margin (TGMM) is the highest in channel III which is about $26.1 \%$ and lowest $20 \%$ in channel II. Producer's share (GMMp) is highest (80\%) from the total consumers' price in channel II and lowest in channel III (73.9\%) because of the involvement of rural assemblers in this channel. Retailers have got higher marketing margin which is $15.2 \%$ whereas local collectors have got lower marketing margin which is $10.9 \%$ (Table 3 ).

\section{Conclusion}

Given the large potential for fruit production in the country, their contribution to the total output has been extremely low [13-17]. The most cited reasons include lack of market-oriented production which is too traditional; excessive margin mainly due to inefficient and costly transport; absence of fruit market information; and absence of market regulations and legislations and its marketing activity is principally attributed to poor actors' skill. As a result, fruit marketing needs due attention in any on-going or future fruit development plan.

\section{Acknowledgement}

None.

\section{Conflict of Interest}

No conflict of interest.

\section{References}

1. Tewodros Bezu, et al. (2014) Production Scenarios of Mango (Mangifera indica L) in Harari Regional State, Eastern Ethiopia Science, Technology and Arts Research Journal Sci Technol Arts Res J 3(4): 59-63.

2. Leake Gebresilassie, Bereket Gebremedhin, Tedros Girma, Fikremariam Birara (2015) apple mango value chain in northern ethiopia: case study of mereb-leke district agro-science Journal of Tropical Agriculture, Food, Environment and Extension 14(3): 16-21.

3. Seid Hussen and Zeru Yimer (2013) Assessment of Production Potentials and Constraints of Mango (Mangifera indica) at Bati, Oromiya Zone Ethiopia International Journal of Sciences: Basic and Applied Research (IJSBAR).
4. Mesay Adugna (2017) Strategic Analysis of Mango (Mangifera indica) Value Chain in Dilla Zuriya District, Dilla Ethiopia International Journal of Plant \& Soil Science 16(1): 1-12.

5. CSA (2009) Agricultural sample survey: report on area and production for major crops, statistical bulletin 427.Addis Ababa, Ethiopia

6. IPMS (Improving Productivity and Market Success) (2011) Fruits-A synthesis of IPMS value-chain development experiences.

7. Ayelech T (2011) Market chain analysis of fruits for Goma woreda, Jimma zone, Oromia regional state; A Thesis Submitted to School of Graduate Studies of Haramaya University, pp. 1-127.

8. Bezabih E (2010) Market Assessment and Value Chain Analysis in Benishangul Gumuz Regional State, Ethiopia; Final Report, SID- ConsultSupport Integrated DevelopmentAddis Ababa, pp. 1-95.

9. Leake Gebresilassie, Bereket Gebremedhin, Tedros Girma, Fikremariam Birara (2015) Apple mango value chain in northern ethiopia: case study of mereb-leke district Agro-Science Journal of Tropical Agriculture, Food, Environment and Extension 14(3): 16-21.

10. CSA (2013) Agricultural Sample Survey 2012/2013, Report on Area and Production of Major Crops, Statistical Bulletin 532; Addis Ababa, Ethiopia, Volume I.

11. Takele Honja (2014) Review of Mango Value Chain in Ethiopia Journal of Biology, Agriculture and Healthcare, 4(25).

12. Nega Mateows, Teshale Wolde Amanuel, Zebene Asfaw (2015) Market Chain Analysis of Agro-forestry Products: The Case of Fruit at Tembaro District, Kembata Tembaro Zone South Ethiopia. International Journal of Business and Economics Research. 4(4): 201-216.

13. Getahun, Eskinder Yigezu, Desalegn Alemayehu (2017) Market Chain Analysis of HighValue Fruits in Bench Maji Zone, Southwest Ethiopia International Journal of Marketing Studies 9(3):124.

14. Ishot (2009) Study of regional potential resources. HarariStates' Office of the President Diaspora Office, Harar, 1(1).

15. Kitnoja L (2010) Identification of appropriate postharvest technologies for improving market access and incomes for small horticultural farmers in Sub-saharan Africa and South Asia. WFLO grant final report to the Bill and Melinda Gates Foundation, Pp. 3-8.

16. Melaku Haile Market Value Chain Analysis of Mango: The Case of Arbaminch Zuria Woreda, Arba Minch University.

17. MoARD (Ministry of Agriculture and Rural Development) (2009) Improved technologies and resource management for Ethiopian agriculture. A Training Manual. RCBP-MoARD, Addis Ababa, Ethiopia. 